\title{
FORMATION BEHAVIOUR OF SPINEL-CaS MULTIPHASE INCLUSIONS IN Ca-TREATED RESULPHURISED STEEL DURING THE LADLE FURNACE PROCESS
}

\author{
NASTANEK VEČFAZNIH SPINEL-CaS VKLJUČKOV V \\ NAŽVEPLANI JEKLENI TALINI, OBDELANI S Ca MED \\ POSTOPKOM SEKUNDARNE METALURGIJE
}

\author{
Luka Krajnc ${ }^{1}$, Jaka Burja ${ }^{2 *}$, Jožef Medved ${ }^{3}$, Tae Sung Kim ${ }^{4}$, Joo Hyun Park ${ }^{4,5}$ \\ ${ }^{1}$ Pro Labor d.o.o., Podvin 20, 3310 Žalec, Slovenia \\ 2Institute for Metals and Technology, Lepi pot 11, 1000 Ljubljana, Slovenia \\ ${ }^{3}$ Department of Materials and Metallurgy, Faculty of Natural Sciences and Engineering, University of Ljubljana, \\ Aškerčeva 12, 1000 Ljubljana, Slovenia \\ ${ }^{4}$ Department of Materials Engineering, Hanyang University, Ansan 15588 Korea \\ ${ }^{5}$ Department of Materials Science and Engineering, KTH Royal Institute of Technology, Stockholm 100 44, Sweden
}

Prejem rokopisa - received: 2019-12-04; sprejem za objavo - accepted for publication: 2020-03-29

doi:10.17222/mit.2019.288

\begin{abstract}
The formation of multiphase inclusions was investigated in resulphurised steel. Samples were taken at different stages of the steelmaking process, from primary deoxidation through calcium modification and sulphur addition to casting. Chemical analyses were made on all the samples, from which thermodynamic calculations using thermochemical computing software were performed, to determine which phases are stable at any given stage of the steelmaking process. Inclusions were investigated using a scanning electron microscope and automatic inclusion analysis software. The presentation of the automatic inclusion analysis results in the form of ternary diagrams provides an insight into the calcium modification of inclusions and the change of the inclusions' size and chemical composition after sulphur addition. Based on the results from this study, a formation mechanism is proposed for spinel-CaS multiphase inclusions in resulphurised steel.

Keywords: non-metallic inclusion, automatic inclusion analysis, calcium treatment, resulphurised steel

Preiskovali smo nastanek večfaznih nekovinskih vključkov v nažveplanem jeklu. Vzorce jekla smo jemali med različnimi stopnjami jeklarskega procesa, od primarne dezoksidacije, obdelave s kalcijem in nažveplanja do litja. Vse vzorce smo kemijsko analizirali. Rezultate kemijskih analiz smo uporabili za termodinamske izračune s programsko opremo. Rezultat so bili preračuni nastanka ravnotežnih faz pri različni stopnjah izdelave jekla. Vključke smo analizirali z vrstičnim elektronskim mikroskopom, opremljenim s programsko opremo za avtomatsko analizo vključkov. Rezultati avtomatske analize vključkov so predstavljeni v ternarnih diagramih in prikazujejo vpliv modifikacije nekovinskih vključkov s kalcijem in dodatka žvepla na kemijsko sestavo in velikost vključkov. Glede na dobljene rezultate smo predlagali mehanizem nastanka večfaznih spinel-CaS nekovinskih vključkov v nažveplanem jeklu.

Ključne besede:nekovinski vključki, avtomatska analiza vključkov, obdelava s kalcijem, nažveplano jeklo
\end{abstract}

\section{INTRODUCTION}

Sulphide non-metallic inclusions (NMIs) have become synonymous with steel machinability. ${ }^{1-3}$ However, the addition of sulphur significantly complicates the engineering of oxide inclusions because it has high affinity towards calcium. ${ }^{4-9}$ Calcium is very widely used for the modification of oxide inclusions, predominantly alumina and spinel, which are hard and brittle and cause nozzle clogging during the continuous casting of steel. ${ }^{10-22}$ The formation of alumina inclusions is the consequence of deoxidation with aluminium. Additionally, high aluminium contents in the steel create favourable conditions for spinel $\left(\mathrm{MgAl}_{2} \mathrm{O}_{4}\right)$ formation. A single spinel inclusion forms by the aluminium reacting with a magnesium oxide source (refractory and/or slag), while

*Corresponding author's e-mail: jaka.burja@imt.si (Jaka Burja) spinel surrounded by aluminosilicate forms during crystallization of the aluminosilicate inclusion. ${ }^{23,24}$

Calcium additions to steel result in $\mathrm{CaO}$ and $\mathrm{CaS}$ formation. ${ }^{25,26}$ The reaction between $\mathrm{CaO}$ and $\mathrm{Al}_{2} \mathrm{O}_{3}$ results in low melting oxides, i.e., modified oxide $\left(12 \mathrm{CaO} \cdot 7 \mathrm{Al}_{2} \mathrm{O}_{3}\right)$. The modification of alumina inclusions is controlled by the calcium diffusion in alumina. ${ }^{27}$ Consequently, complete modification of the spinel inclusion is possible when they are relatively small, up to $2 \mu \mathrm{m}$, whereas larger inclusions (above $5 \mu \mathrm{m}$ ) result in multiphase NMIs. ${ }^{28}$ Additionally, low $\mathrm{MgO}$ contents in calcium-aluminate inclusions even increases their liquidity. ${ }^{29}$ The $\mathrm{Ca}$ addition also potentially reduces the $\mathrm{MgO}$ in the slag and/or inclusions, so the $\mathrm{Mg}$ content in the steel increases in conjunction with the increase in the $\mathrm{CaO}$ content in the spinel inclusion. ${ }^{30,31}$

When sulphur is added to steel, favourable conditions are met for the formation of multiphase NMIs. ${ }^{32}$ J. H. Shin et al. ${ }^{33}$ proposed a formation mechanism for 
oxide-sulphide complex inclusions, where $\mathrm{CaO}$ is depleted from the multiphase $\mathrm{CaO}-\mathrm{Al}_{2} \mathrm{O}_{3}-\mathrm{MgO}-\mathrm{SiO}_{2}$ inclusion system to form $\mathrm{CaS}$ on the surface of the inclusions. Consequently, the $\mathrm{Al}_{2} \mathrm{O}_{3}$ and $\mathrm{MgO}$ are enriched in the core of the inclusions. However, the study was investigated without calcium additions on a laboratory scale. Because the multiphase inclusions have been found to clog the nozzle on a continuous casting machine, ${ }^{34,35}$ we investigated the formation mechanism of oxide-sulphide multiphase inclusions in commercial plants manufacturing the resulphurised steels. The aim of this work was to determine what happens to the NMIs when a calcium treatment is applied to a resulphurised steel melt. Are the alumina and spinel inclusions really modified, and how does it affect the sulphide inclusions?

\section{EXPERIMENTAL PART}

Steel samples marked \#1-6 were taken during a secondary metallurgy treatment of a resulphurised steel grade. 1) Before and 2) after calcium treatment, (3) before and (4) after sulphur addition, (5) $20 \mathrm{~min}$ after sulphur addition and (6) at the end of the ladle treatment.

The samples were taken using the Sample-on-Line method. Chemical analyses of the samples were carried out using optical emission spectroscopy (OES, Spectro LAVMC12A). Additionally, the carbon and sulphur were measured with an Eltra CS800. The samples were metallographically prepared and analysed using a scanning electron microscope with energy-dispersive spectroscopy (SEM-EDS, JEOL JSM-6390. Two slag samples were taken during the ladle treatment: one before the sulphur addition, simultaneously with sample \#3, and one after the sulphur addition, simultaneously with sample \#5. The chemical composition of the slag samples was determined using an X-ray fluorescence spectrometer (XRF, Thermo Scientific Niton XL3t GOLDD+). The process flow and sampling positions are shown in Figure 1.

The chemical composition and size of each NMI was analysed by an automatic inclusions analysis system using a ZEISS SUPRA 55 VP SEM. The average chemical composition of each inclusion was calculated in relation to the inclusion size. The content of a specific element in a NMI was multiplied by the size of that

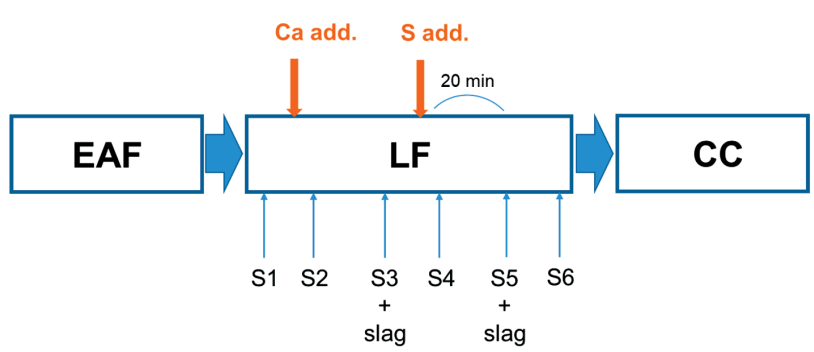

Figure 1: Process flow and sampling position for steel and slag samples. EAF-electric arc furnace, LF-ladle furnace, CC-continuous casting. inclusion and subtracted by the total inclusion area, from which the average element content in the inclusion was calculated using Equation (1):

$$
\bar{X}=\frac{\sum_{i}^{n} A_{i} X_{i}}{\sum_{i}^{n} A_{i}}
$$

Where $\bar{X}$ is the average composition of the NMI, $A_{i}$ is the area of the analysed inclusion, $X_{i}$ is the composition of the analysed inclusion. The thermodynamic calculation for inclusion-steel equilibria was performed with Themo-Calc ${ }^{\circledR}$ TCW5 software. The calculations were made using the SSUB3 and SLAG1 databases.

\section{RESULTS}

The chemical compositions of the steel and slag samples are presented in Table $\mathbf{1}$ and Table 2, respectively.

Table 1: Chemical composition of steel samples (w/\%)

\begin{tabular}{|c|c|c|c|c|c|c|}
\hline $\begin{array}{c}\text { Sample } \\
\text { No. }\end{array}$ & $\mathrm{C}$ & $\mathrm{Si}$ & $\mathrm{Mn}$ & $\mathrm{S}$ & $\mathrm{Al}$ & $\mathrm{Ca}$ \\
\hline 1 & 0.27 & 0.59 & 1.43 & 0.012 & 0.022 & 0.0002 \\
\hline 2 & 0.28 & 0.63 & 1.42 & 0.011 & 0.021 & 0.0065 \\
\hline 3 & 0.28 & 0.63 & 1.43 & 0.010 & 0.021 & 0.0048 \\
\hline 4 & 0.28 & 0.63 & 1.42 & 0.049 & 0.020 & 0.0055 \\
\hline 5 & 0.29 & 0.63 & 1.43 & 0.045 & 0.019 & 0.0025 \\
\hline 6 & 0.29 & 0.62 & 1.42 & 0.036 & 0.018 & 0.0010 \\
\hline
\end{tabular}

Table 2: Chemical composition of slag samples (w/\%)

\begin{tabular}{|c|c|c|c|c|c|c|c|}
\hline $\begin{array}{c}\text { Sample } \\
\text { No. }\end{array}$ & $\mathrm{SiO}_{2}$ & $\mathrm{Al}_{2} \mathrm{O}_{3}$ & $\mathrm{FeO}$ & $\mathrm{MnO}$ & $\mathrm{CaO}$ & $\mathrm{MgO}$ & $\mathrm{S}$ \\
\hline $3-\mathrm{S}$ & 14.8 & 15.9 & 1.5 & 0.2 & 63.1 & 3.1 & 1.5 \\
\hline $5-\mathrm{S}$ & 15.2 & 15.4 & 1.3 & 0.7 & 61.9 & 2.6 & 3.0 \\
\hline
\end{tabular}

The chemical composition of slag did not change significantly during the secondary metallurgy process. There was a slight increase in $\mathrm{SiO}_{2}$ content, as seen in Table 2. Based on the chemical composition of the steel samples, thermodynamic calculations were performed for the sulphide inclusion. The calculated percentage of

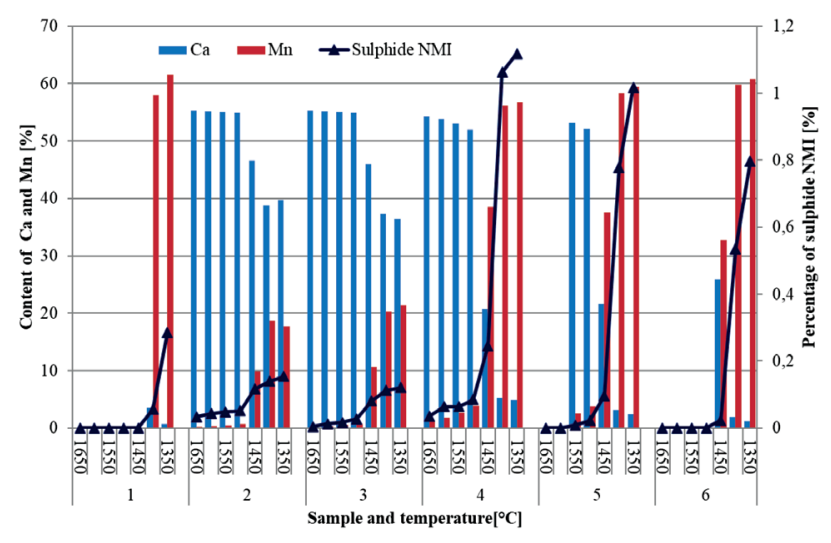

Figure 2: Percentage of sulphide inclusions and the content of $\mathrm{Ca}$ and $\mathrm{Mn}$ in these inclusions for all the samples at different temperatures 
sulphide inclusion and the content of $\mathrm{Ca}$ and $\mathrm{Mn}$ in these inclusions are shown in Figure 2. The percentage of stable sulphides is calculated at different temperatures from $1923 \mathrm{~K}$ to $1623 \mathrm{~K}$ for all the samples. When $\mathrm{Ca}$ is added, the stability of the CaS is greatly increased. The $\mathrm{CaS}$ inclusions are stable at high temperatures, while the $\mathrm{MnS}$ precipitates during solidification. The lower temperatures contribute to the large increase in sulphide inclusions. The $\mathrm{CaS}$ are stable only at high temperatures as the $\mathrm{Ca}$ content decreases. The increase in sulphur content also increases the number of sulphides and the temperature of the sulphide precipitation.

In sample \#1, before the addition of calcium, there are no thermodynamically stable sulphides in liquid steel. With the addition of calcium (sample \#2), the percentage of $\mathrm{CaS}$ in liquid steel slightly increases and $\mathrm{CaS}$ is predominantly stable during the solidification. The situation is similar before the addition of sulphur, only the percentage of sulphides is smaller. After the
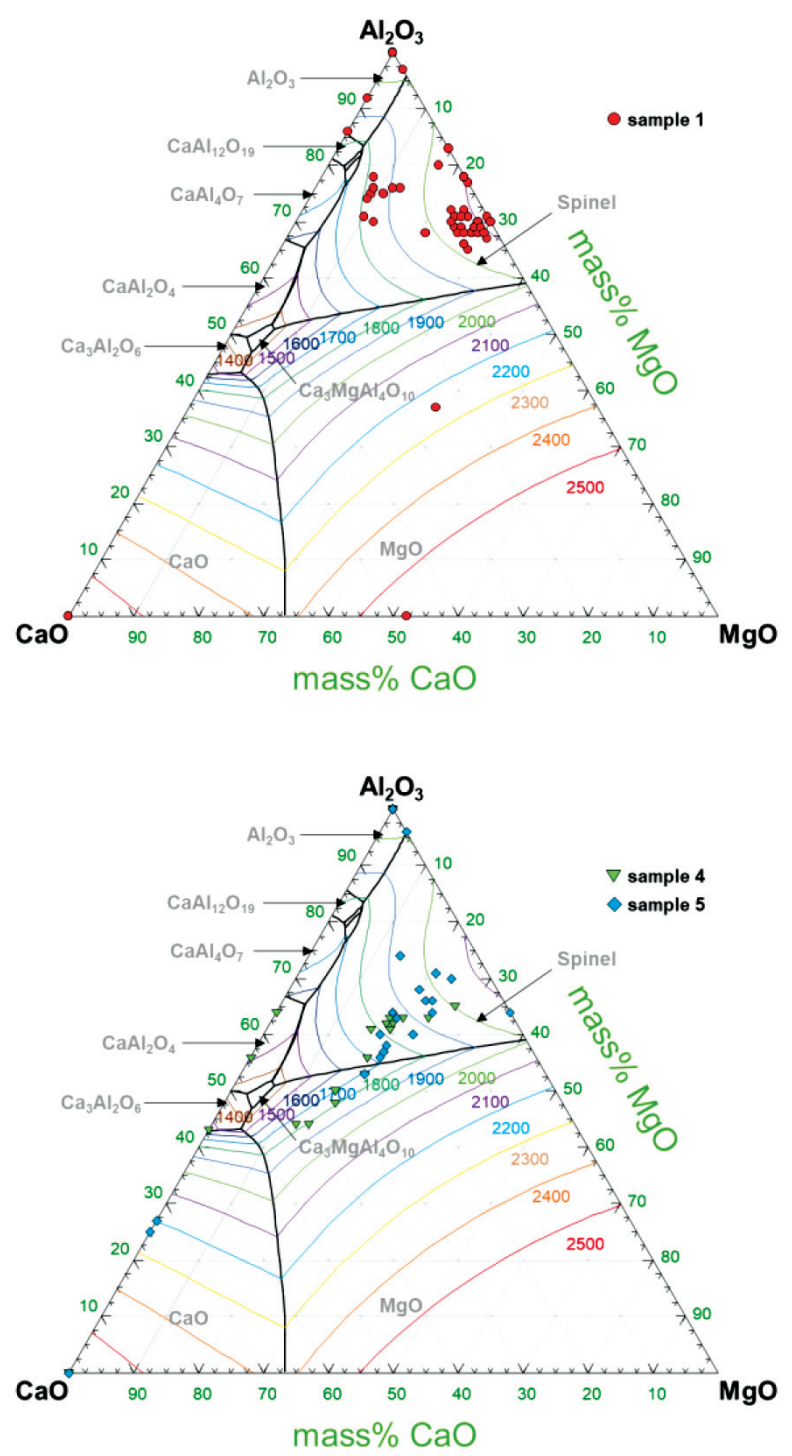

sulphur addition (sample \#4), a larger percentage of CaS is stable in liquid steel and a significantly larger percentage of $\mathrm{MnS}$ is stable during the solidification of the steel. In samples \#5 (20 min after sulphur addition) and \#6 (end of LF treatment), a decrease in the percentage of primary $\mathrm{CaS}$ and secondary $\mathrm{MnS}$ can be found.

The results of the automatic inclusion analysis are presented in the $\mathrm{CaO}-\mathrm{MgO}-\mathrm{Al}_{2} \mathrm{O}_{3}$ ternary diagram for the oxide and oxysulphide inclusions in Figure $\mathbf{3}$ and Figure 4, respectively. The solid dots indicate a single type of NMI. Before calcium addition (sample \#1), the inclusions are mainly alumina and spinel. After the calcium addition (sample \#2), the spinel inclusions are modified to the $\mathrm{CaO}-\mathrm{Al}_{2} \mathrm{O}_{3}-\mathrm{MgO}$ inclusions. The situation is similar in the next step (sample \#3), whereas the number of inclusions is slightly decreased. With the addition of sulphur (sample \#4), the total number of oxide inclusions decreases and the same is true for
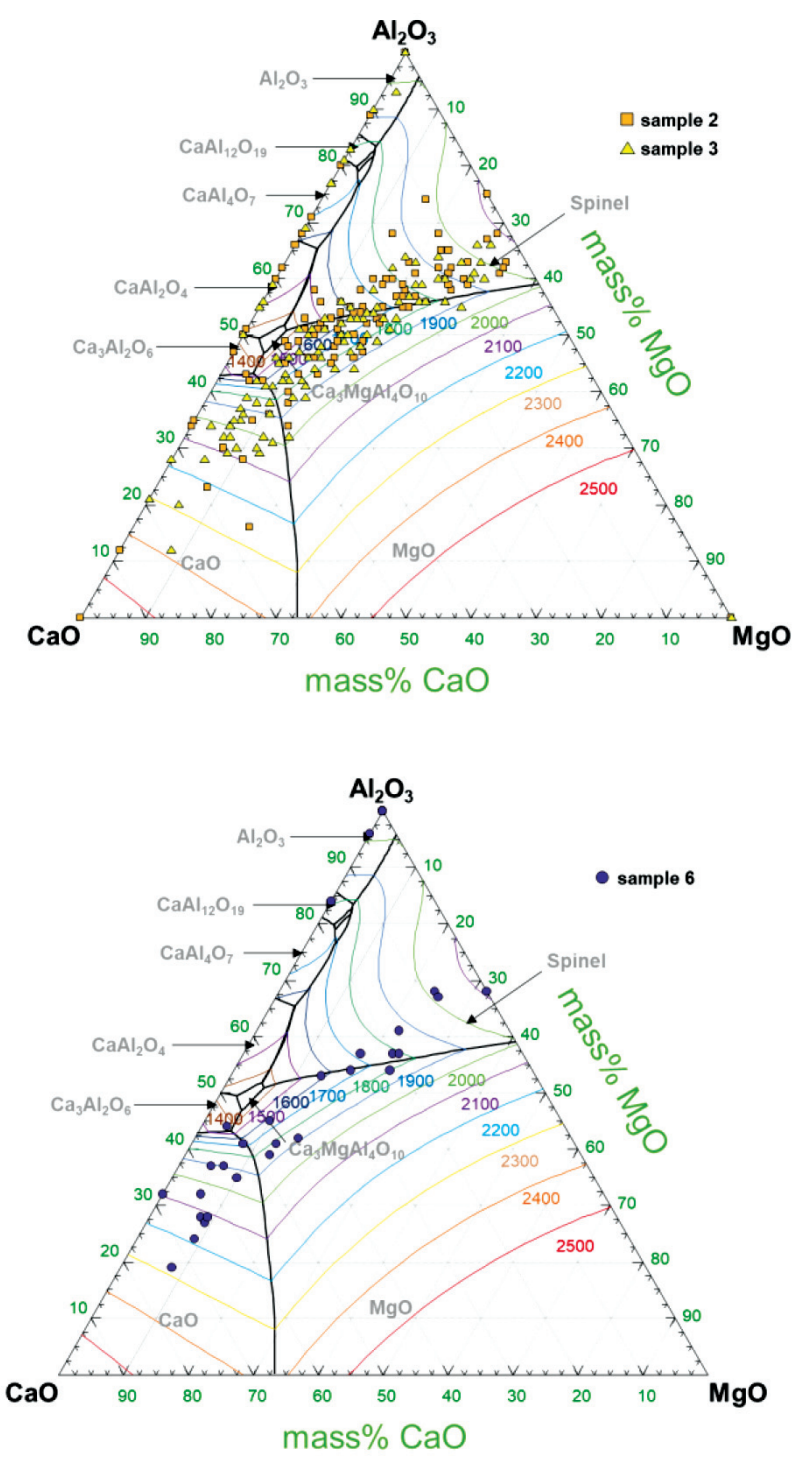

Figure 3: Distribution of multiphase NMI in the $\mathrm{CaO}-\mathrm{MgO}-\mathrm{Al}_{2} \mathrm{O}_{3}$ ternary diagram in all six samples 


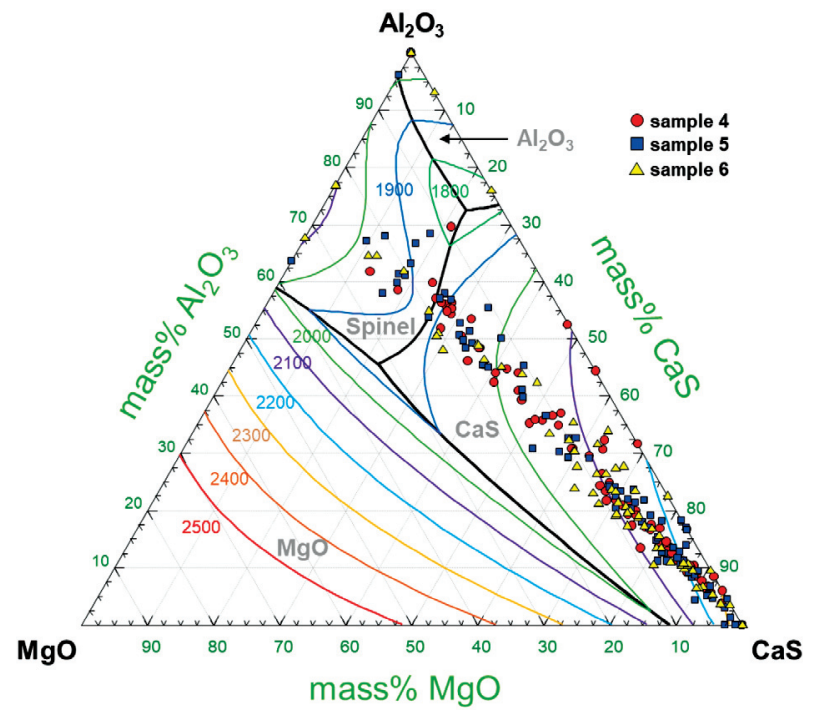

Figure 4: Distribution of multiphase NMI in the CaS-MgO- $\mathrm{Al}_{2} \mathrm{O}_{3}$ ternary diagram for samples \#4, \#5 and \#6

sample \#5, and shows a small increase in numbers in sample \#6 (at the end of LF treatment).

In Figure 4, the results of the automatic inclusion analysis are presented in the $\mathrm{CaS}-\mathrm{MgO}-\mathrm{Al}_{2} \mathrm{O}_{3}$ ternary diagram for samples \#4, \#5 and \#6. Some inclusions are scarcely on the pure $\mathrm{Al}_{2} \mathrm{O}_{3}$-corner or the $\mathrm{CaS}$-corner, whereas the majority of the inclusions are complex and positioned on the spinel-CaS conjugation line with a variation of oxide/sulphide ratio. The typical morphology of the complex NMI is presented in Figure 5. The dark phase is spinel, the dark-grey phase is modified calcium aluminate, and the light-grey phase is CaS.

The calculated area of elements for all the inclusions found using an automatic inclusion analysis system is presented in Figure 6, which provides a clearer understanding of the combined chemical composition of the inclusions in different samples. The total area of the NMIs is relatively small before the calcium treatment (sample \#1) and is composed mostly of MnS and some spinel. After the calcium addition (sample \#2), the total area of NMIs increases slightly and the composition
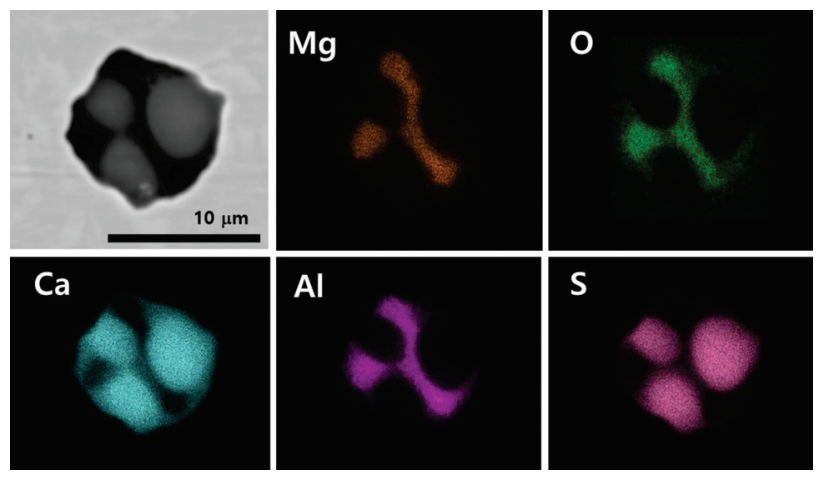

Figure 5: Back-scattered electron image and element mapping results for the multiphase inclusions found in sample \#5
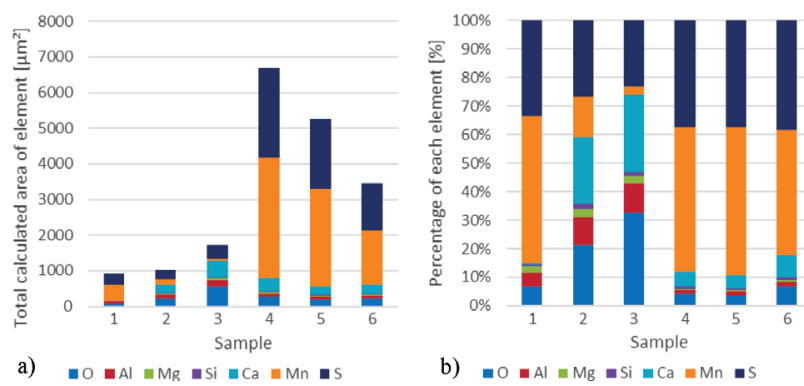

Figure 6: a) Calculated area of elements for all NMI in $\mu \mathrm{m}^{2}$ and b) converted content of elements $(w / \%)$

changes significantly in favour of calcium aluminates in general.

In sample \#3, this trend continues, with calcium supplementing the manganese in sulphide inclusions and their area fraction increases. The magnesium content is similar in samples \#1 to \#3. However, the absolute amount of magnesium in the NMIs is higher as the total area increases. A significant increase in the total area (specifically MnS) occurs with the sulphur addition (sample \#4). The area of $\mathrm{MnS}$ then decreases in samples \#5 and \#6. The area fraction of calcium in sample \#5 decreases slightly, whereas the oxygen and aluminium area decreases by half. This trend also continues in samples \#5 and \#6.

\section{DISCUSSION}

Before the addition of calcium, only alumina, spinel and some MnS inclusions are found in molten steel. Their total area fraction is relatively small. After the addition of calcium, the vast majority of the NMIs become modified, i.e., there is an increase in oxide inclusions and a decrease in sulphides where calcium replaces the manganese. Twenty minutes after the calcium treatment, before the sulphur addition, calcium has had a longer time to react with the inclusions, and therefore their total area fraction increases significantly. Because calcium further replaces the manganese in the sulphides, more oxygen is also present in these inclusions. After the sulphur addition, a bunch of $\mathrm{MnS}$ are formed. Towards the end of the LF treatment, the total area fraction of NMI decreases, most notably of sulphides but also oxides. This is due to the interaction with the top slag and the removal of the inclusion particles.

The inclusion evolution path observed in the present test is presented in Figure 7 and can be described as follows.

The alumina inclusions react with magnesium, which is transferred from slag and/or refractory, to form spinel type NMIs.

After the calcium addition, the alumina and spinel inclusions are either modified into liquid or partially modified $\mathrm{CaO}-\mathrm{Al}_{2} \mathrm{O}_{3}$ and $\mathrm{CaO}-\mathrm{Al}_{2} \mathrm{O}_{3}-\mathrm{MgO}$ system inclusions. 


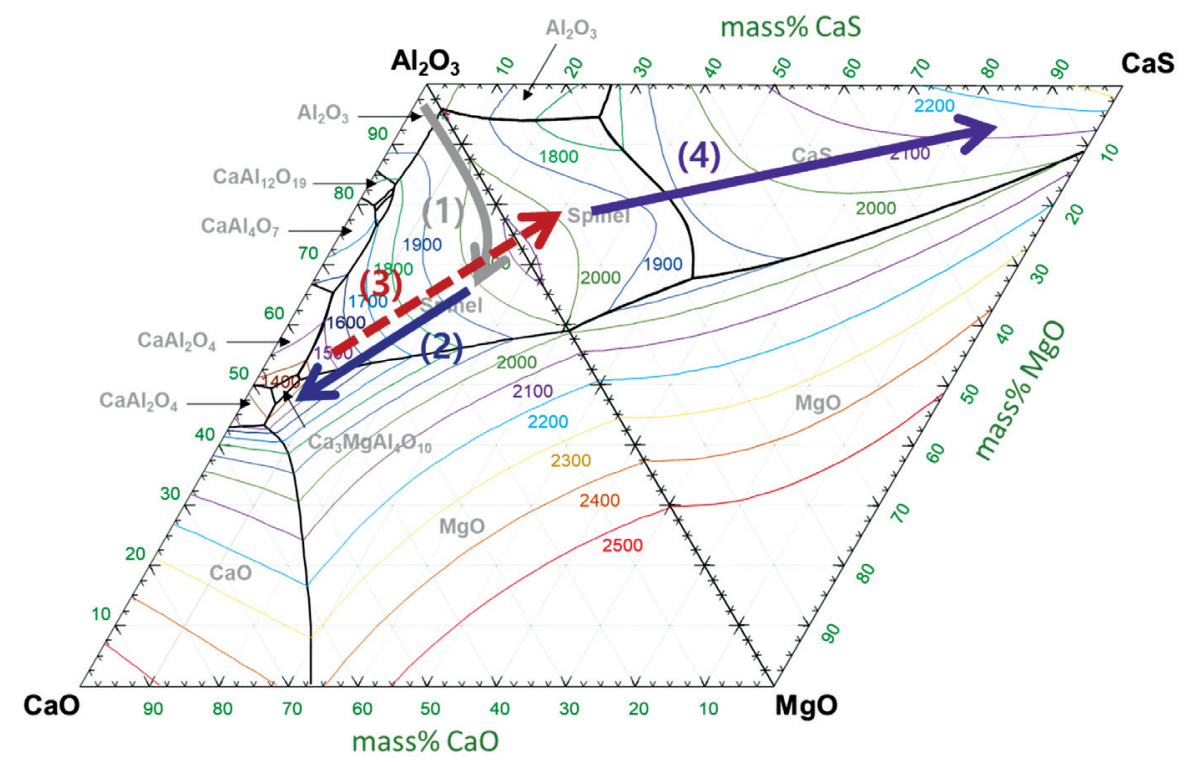

Figure 7: Evolution path of inclusion chemistry in the present test for resulphurised steel

After the sulphur addition, the modification of the NMIs ceased and CaS is formed.

The area fraction of $\mathrm{CaS}$ phase in the complex inclusions increases until the end of the ladle treatment.

The NMIs found in samples \#4 to \#6 are, in the majority, secondary manganese sulphide and primary multiphase system, which is presented in Figures $\mathbf{2}$ and 6. In primary multiphase inclusions, the $\mathrm{CaS}$ phase is predominant, and spinel phase is present to a lesser extent. The formation mechanism of these complex inclusions is presented in Figure 8. They are formed when the spinel type inclusion is too large (Figure 8a) to be modified by calcium and forms a two-phase NMI of spinel and calcium aluminate phase (Figure 8b). After the sulphur addition, the modification process ceases (Figure 8c), and the calcium reacts with sulphur to form the $\mathrm{CaS}$ phase, and with time this phase continues to grow (Figure 8d to 8f).

The proposed mechanism differs from the one proposed by J. H. Shin et al., ${ }^{33}$ where the liquid $\mathrm{CaO}-\mathrm{Al}_{2} \mathrm{O}_{3}-\mathrm{MgO}-\mathrm{SiO}_{2}$ (CAMS) inclusions are considered as a starting point in laboratory-scale experiments without the $\mathrm{Ca}$ treatment. The source of $\mathrm{Ca}$ in their study was $\mathrm{CaO}$ reduction in the top slag by $\mathrm{Al}$ in molten steel, i.e., $(\mathrm{CaO})+[\mathrm{Al}]=\left(\mathrm{Al}_{2} \mathrm{O}_{3}\right)+[\mathrm{Ca}]$. The details for the inclusion modification reaction by calcium transferred from the slag phase are available elsewhere. ${ }^{36-38}$ However, in the current study, the partially modified spinel-type inclusions are considered as a starting point. It depends on the size of the initial spinel inclusion. If they are larger than $5 \mu \mathrm{m}$, they cannot be fully modified by the calcium treatment; however, if they are smaller than $2 \mu \mathrm{m}$, they can be fully modified..$^{28}$

The comparison of the results obtained from automatic inclusion analysis and thermodynamic calculation is presented in Figure 9. The mass fractions of $\mathrm{Mn}$ and
$\mathrm{Ca}$ in the sulphide inclusions calculated using Thermo$\mathrm{Calc}^{\circledR}$ software are presented in dotted lines, in which sulphur is the balance. The mass fractions of $\mathrm{Mn}, \mathrm{Ca}$ and
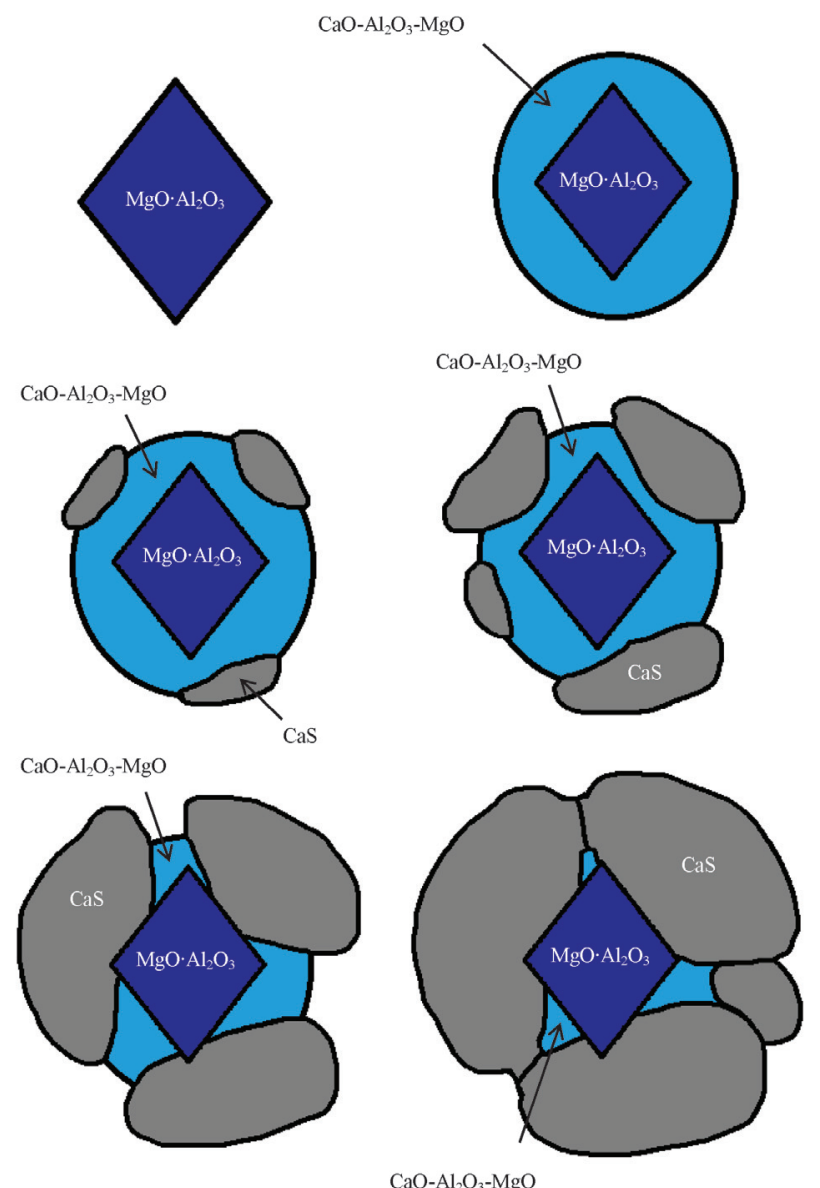

Figure 8: Evolution procedure of spinel-sulphide multiphase NMI in resulphurised steel 


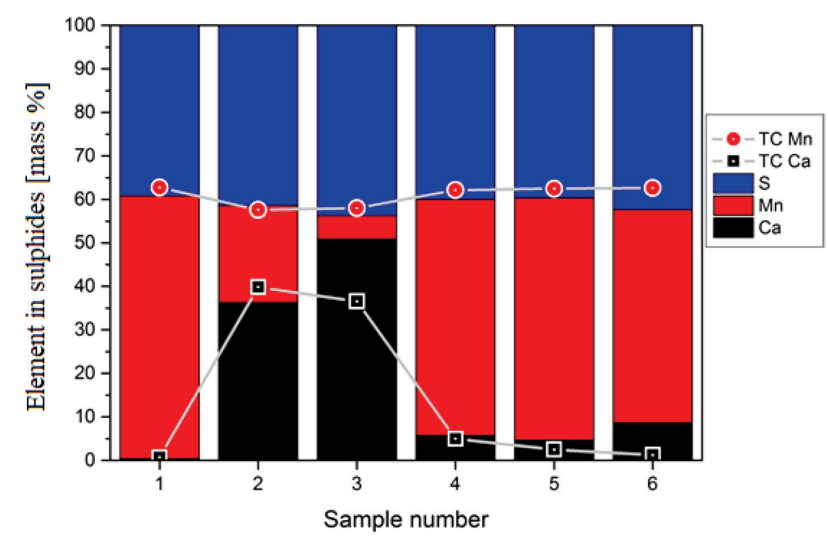

Figure 9: Comparison of the mass fraction of the thermodynamically stable $\mathrm{Mn}, \mathrm{Ca}$ and $\mathrm{S}$ in the sulphide inclusions at $1623 \mathrm{~K}$ and area fractions of these elements in the inclusions found with automatic inclusion analysis for all samples.

$\mathrm{S}$ in the sulphide NMIs obtained by an automatic inclusion analysis are presented in coloured columns. The thermodynamic calculations are in good agreement with the experimental findings for the manganese and sulphur contents in the inclusions, whereas some scatter is observed for the calcium content. Higher $\mathrm{Ca}$ contents in the molten steel do not result in a higher $\mathrm{Ca}$ content in the NMIs, which originated from the non-equilibrium conditions in the plant tests. The inclusion modification reaction using the $\mathrm{Ca}$ treatment needs time. The addition of $\mathrm{Ca}$ increases the $\mathrm{Ca}$ content in molten steel and the thermodynamic calculation predicts the highest content of $\mathrm{Ca}$ in the inclusions. Nevertheless, there is little calcium found with the automatic inclusion analysis. After some time, the Ca content in the steel decreases, while the calcium found in the NMIs with the automatic inclusion analysis slightly increases (samples \#4 to \#6).

In summary, to understand which inclusions are present in the liquid steel during the LF treatment of the resulphurised steel, we need to take two things into account: First, if we look at the results of the thermodynamic calculations, we need to consider the reaction kinetics of different elements with the NMIs. Second, if we look at the results of an automatic inclusion analysis, we need to consider that a significant number of secondary inclusions formed during the steel solidification. This is specifically the case with resulphurised steel grades. Hence, finally, it is better to recommend the operating conditions to suppress or decrease the harmful inclusions during the refining and casting of resulphurised steels.

\section{CONCLUSIONS}

The thermodynamic calculations provide good results for the NMI type and phase stability in steel as a function of temperature. The correlation is much higher for sulphide inclusions. At steelmaking temperatures, the $\mathrm{CaS}$ inclusion is stable when the calcium and sulphur contents are high enough. The correlation between the amounts of $\mathrm{MnS}$ inclusion predicted by thermodynamic calculations and the measured number of $\mathrm{MnS}$ using automatic inclusion analysis is relatively high.

A higher content of sulphur in the steel makes it more difficult for calcium to modify the alumina and spineltype inclusions. Alternatively, $\mathrm{CaS}$ is formed, which is, the same as alumina, detrimental to the castability of steel.

If sulphur is added prematurely after the addition of the calcium, the spinel inclusions are not completely modified and because of the high contents of both calcium and sulphur, optimum conditions will be met for the CaS phase to form on the surface of the spinel inclusions.

\section{REFERENCES}

${ }^{1}$ X. Zhang, H. Roelofs, S. Lemgen, U. Urlau, S. V. Subramanian, Application of thermodynamic model for inclusion control in steelmaking to improve the machinability of low carbon free cutting steels, Steel Res. Int., 75 (2004) 314-321, doi:10.1002/srin. 200405961

${ }^{2}$ S. V. Subramanian, H.O. Gekonde, G. Zhu, X. Zhang, U. Urlau, H. Roelofs, Inclusion engineering of steel to prevent chemical tool wear, Ironmak. Steelmak., 31 (2004) 249-257, doi:10.1179/ 030192304225018055

${ }^{3}$ N. Matsui, K. Watari, Wear Reduction of Carbide Tools Observed in Cutting Ca-added, 46 (2006) 1720-1727

${ }^{4}$ Y. Wang, S. Sridhar, M. Valdez, Formation of $\mathrm{CaS}$ on $\mathrm{Al}_{2} \mathrm{O}_{3}-\mathrm{CaO}$ inclusions during solidification of steels, Metall. Mater. Trans. B., 33 (2002) 625-632, doi:10.1007/s11663-002-0042-1

${ }^{5}$ F. Li, H. Li, D. Huang, S. Zheng, J. You, Mechanism of MnS Precipitation on $\mathrm{Al}_{2} \mathrm{O}_{3}-\mathrm{SiO}_{2}$ Inclusions in Non-oriented Silicon Steel, Met. Mater. Int., 24 (2018) 1394-1402. doi:10.1007/s12540-018-0141-4

${ }^{6}$ F. Y. Huang, Y. H. F. Su, J. C. Kuo, High-Temperature Deformation Behavior of MnS in 1215MS Steel, Met. Mater. Int., 24 (2018) 1333-1345, doi:10.1007/s12540-018-0137-0

${ }^{7}$ J. Lu, G. Cheng, J. Che, L. Wang, G. Xiong, Effect of Oxides on Characteristics of MnS and Transverse Mechanical Properties in Commercial Al-Killed Non-Quenched and Tempered Steel, Met. Mater. Int., 25 (2019) 473-486, doi:10.1007/s12540-018-0191-7

${ }^{8}$ C. E. Cicutti, J. Madías, J. C. González, Control of microinclusions in calcium treated aluminium killed steels, Ironmak. Steelmak., 24 (1997) 155-159

${ }^{9}$ L. Krajnc, G. Klančnik, P. Mrvar, J. Medved, Thermodynamic analysis of the formation of non-metallic inclusions during the production of C45 steel, Mater. Tehnol., 46 (2012) 361-368

${ }^{10}$ D. Z. Lu, G. A. Irons, W. K. Lu, Kinetics and Mechanisms of Calcium Dissolution and Modification of Oxide and Sulphide Inclusions in Steel, Ironmaking and Steelmaking, 21 (1994) 5, 362-371

${ }^{11}$ Y. Higuchi, M. Numata, S. Fukagawa, K. Shinme, Inclusion Modification by Calcium Treatment, ISIJ Int., 36 (1996) 51-54

${ }^{12} \mathrm{~S}$. K. Choudhary, A. Ghosh, Thermodynamic evaluation of formation of oxide-sulfide duplex inclusions in steel, ISIJ Int., 48 (2008) 1552-1559, doi:10.2355/isijinternational.48.1552

${ }^{13}$ V. Prešern, B. Koroušić, J.W. Hastie, Thermodynamic conditions for inclusions modification in calcium treated steel, Steel Res. 62 (1991) 289-295, doi:10.1002/srin.199101297

${ }^{14}$ G. Ye, P. Jönsson, T. Lund, Thermodynamics and kinetics of the modification of A12O3 inclusions, ISIJ Int., 36 (1996) 105-108, doi:10.2355/isijinternational.36.suppl_s105 
${ }^{15}$ F. Tehovnik, J. Burja, B. Arh, M. Knap, Submerged entry nozzle clogging during continuous casting of Al-killed steel, Metalurgija, 54 (2015) 371-374

${ }^{16}$ Y. Kusano, Y. Kawauchi, M. Wajima, K. Sugawara, M. Yoshida, H Hayashi, Calcium treatment technologies for special steel bars and wire rods, ISIJ Int., 36 (1996) 77-80, doi:10.2355/isijinternational. 36.suppl_s77

${ }^{17}$ J. M. A. Geldenhuis, P. C. Pistorius, Minimisation of calcium additions to low carbon steel grades, Ironmak. Steelmak., 27 (2000) 442-449, doi:10.1179/030192300677769

${ }^{18}$ J. C. S. Pires, A. Garcia, Modification of oxide inclusions present in aluminum-killed low carbon steel by addition of calcium, Rem Rev. Esc. Minas., $57 \quad$ (2004) 183-189, doi:10.1590/S037044672004000300008

${ }^{19}$ M. Lind, PhD Thesis: Mechanism and Kinetics of Transformation of Alumina Inclusions By Calcium Treatment, 2006, doi:10.1016/ S1006-7191(06)60017-3

${ }^{20}$ M. Lind, L. Holappa, Transformation of alumina inclusions by calcium treatment, Metall. Mater. Trans. B Process Metall. Mater. Process. Sci., 41 (2010) 359-366, doi:10.1007/s11663-009-9337-9

${ }^{21}$ S. Abdelaziz, G. Megahed, I. El-Mahallawi, H. Ahmed, Control of $\mathrm{Ca}$ addition for improved cleanness of low C, Al killed steel, Ironmak. Steelmak, 36 (2009) 432-441, doi:10.1179/ 174328109X401578

${ }^{22} \mathrm{~K}$. Tshilombo, Determination of inclusions in liquid steel after calcium treatment, Int. J. Miner. Metall. Mater. 17 (2010) 28-31, doi:10.1007/s12613-010-0105-2

${ }^{23} \mathrm{~J}$. H. Park, H. Todoroki, Control of $\mathrm{MgO} \cdot \mathrm{Al}_{2} \mathrm{O}_{3}$ spinel inclusions in stainless steels, ISIJ Int. 50 (2010) 1333-1346, doi:10.2355/ isijinternational.50.1333.

${ }^{24}$ J. H. Park, Formation mechanism of spinel-type inclusions in highalloyed stainless steel melts, Metall. Mater. Trans. B Process Metall Mater. Process. Sci., 38 (2007) 657-663, doi:10.1007/s11663007-9066-X

${ }^{25}$ N. Verma, P. C. Pistorius, R. J. Fruehan, M. Potter, M. Lind, S. R. Story, Transient inclusion evolution during modification of alumina inclusions by calcium in liquid steel: Part II results and discussion, Metall. Mater. Trans., B Process Metall. Mater. Process.Sci., 42 (2011) 720-729, doi:10.1007/s11663-011-9517-2

${ }^{26}$ N. Verma, P. C. Pistorius, R. J. Fruehan, M. Potter, M. Lind, S. Story, Transient inclusion evolution during modification of alumina inclusions by calcium in liquid steel: Part I background experimental techniques and analysis methods, Metall. Mater. Trans. B Process Metall. Mater. Process. Sci., 42 (2011) 711-719, doi:10.1007/ s11663-011-9516-3

${ }^{27}$ Y. I. Ito, M. Suda, Y. Kato, H. Nakato, K. I. Sorimachi, Kinetics of shape control of alumina inclusions with calcium treatment in line pipe steel for sour service, ISIJ Int. 36 (1996) 48-50, doi:10.2355/ isijinternational.36.suppl_s148

${ }^{28}$ S. Yang, Q. Wang, L. Zhang, J. Li, K. Peaslee, Formation and modification of $\mathrm{MgO} \cdot \mathrm{Al}_{2} \mathrm{O}_{3}$-based inclusions in alloy steels, Metall. Mater. Trans. B Process Metall. Mater. Process. Sci., 43 (2012) 731-750. doi:10.1007/s11663-012-9663-1

${ }^{29}$ N. Verma, P. C. Pistorius, R. J. Fruehan, M. S. Potter, H. G. Oltmann, E. B. Pretorius, Calcium modification of spinel inclusions in aluminum-killed steel: Reaction steps, Metall. Mater. Trans. B Process Metall. Mater. Process. Sci., 43 (2012) 830-840, doi: 10.1007/s11663-012-9660-4

${ }^{30}$ S. F. Yang, J. S. Li, Z. F. Wang, J. Li, L. Lin, Modification of $\mathrm{MgO} \cdot \mathrm{Al}_{2} \mathrm{O}_{3}$ spinel inclusions in Al-killed steel by Ca-treatment, Int. J. Miner. Metall. Mater, 18 (2011) 18-23, doi:10.1007/s12613011-0394-0

${ }^{31}$ J. Björklund, M. Andersson, M. Nzotta, P. Jönsson, The effect of Ladle Treatment on Inclusion Composition in Tool Steel Production, Steel Res. Int., 79 (2008) 261-270

${ }^{32}$ L. Krajnc, P. Mrvar, J. Medved, Thermodynamic characterization of multiphase non-metallic inclusions in re-sulphurised steel grades, Mater. Tehnol., 48 (2014) 923-929

${ }^{33}$ J. H. Shin, J. H. Park, Formation Mechanism of Oxide-Sulfide Complex Inclusions in High-Sulfur-Containing Steel Melts, Metall. Mater. Trans. B Process Metall. Mater. Process. Sci., 49 (2018) 311-324, doi:10.1007/s11663-017-1152-0

${ }^{34}$ J. Lamut, J. Falkus, B. Jurjevec, M. Knap, Influence of inclusions modification on nozzle clogging, Arch. Metall. Mater., 57 (2012) 319-324, doi:10.2478/v10172-012-0029-0

${ }^{35}$ D. Janke, Z. Ma, P. Valentin, A. Heinen, Improvement of castability and quality of continuously cast steel, ISIJ Int. 40 (2000) 31-39, doi:10.2355/isijinternational.40.31.

${ }^{36}$ J. H. Shin, J. H. Park, Effect of $\mathrm{CaO} / \mathrm{Al}_{2} \mathrm{O}_{3}$ ratio of ladle slag on formation behavior of inclusions in $\mathrm{Mn}$ and $\mathrm{V}$ alloyed steel, ISIJ Int., 58 (2018) 88-97, doi:10.2355/isijinternational.ISIJINT-2017-456

${ }^{37}$ J. H. Shin, J. H. Park, Modification of Inclusions in Molten Steel by Mg-Ca Transfer from Top Slag: Experimental Confirmation of the 'Refractory-Slag-Metal-Inclusion (ReSMI)' Multiphase Reaction Model, Metall. Mater. Trans, B Process Metall. Mater. Process, Sci., 48 (2017) 2820-2825. doi:10.1007/s11663-017-1080-Z

${ }^{38}$ J. H. Shin, Y. Chung, J. H. Park, Refractory-Slag-Metal-Inclusion Multiphase Reactions Modeling Using Computational Thermodynamics: Kinetic Model for Prediction of Inclusion Evolution in Molten Steel, Metall. Mater. Trans. B Process Metall. Mater. Process. Sci., 48 (2017) 46-59, doi:10.1007/s11663-016-0734-6 